\title{
Environmental Factors of Sleep Hygiene That Influence The Level of Pain on Criticall ill Patients in Intensive Care Unit
}

\author{
Heru Suwardianto*, Dyah Ayu Kartika Wulan Sari \\ Critical Care Nursing Department, STIKES RS. Baptis Kediri, Indonesia \\ herusuwardianto@gmail.com
}

\begin{abstract}
Patient pain disorders are still often found in critical nursing. The ICU (Intensive Care Unit) environment in the form of room temperature, lighting, and noise levels is rarely observed. The aim of the study was to determine sleep hygiene environmental factors that affect the level of pain in critical patients in the Intensive Care Unit. The research design is descriptive-analytic with factor analysis. The study population was all patients in the ICU. Samples were 170 patients in the ICU according to the inclusion criteria. Independent variables are room temperature, lighting level, and noise level. The dependent variable is the level of pain. The research instruments were CPOT, lux meter, and light meter. Data were collected using observation sheets and analyzed using regression. Result of research showed that the pain scale based on CPOT most respondents had Moderate pain as many as 43 respondents $(50.6 \%)$, that the lighting environment $(40.22 \pm 41.1)$, noise $(60.23 \pm$ $8.5)$, and room temperature $(26.76 \pm 1.2)$ were not directly related to the patient's pain level. Environments factors in this study were not directly related to the pain level. there may be other factors that cause the patient's pain to determine the action, prognosis, and use of a mechanical ventilator
\end{abstract}

Keywords: Critically Ill Patients, Environmental Factors of Sleep hygiene, Pain. 


\section{STRADA Jurnal Ilmiah Kesehatan}

DOI: $10.30994 /$ sjik.v9i1.266

ISSN: 2252-3847 (print); 2614-350X (online)

Vol.9 No.1. May 2020. Page.26-34

\section{BACKGROUND}

Critical patients are patients who experience critical conditions with organ failure of one or more organs, such as the heart, kidney and lung organs. Critical patients usually experience some damage to organs and require intensive care. Critical patients get invasive measures to save the lives of these patients. The patient will experience pain during treatment in the ICU. Pain in critical patients can be caused by medical and nursing prognosis and the environment. The patient's resting environment needs to be considered especially when the patient is resting. Patients rest at night and this time is the best time for patients to rest. The critical patient environment can be in the form of lighting levels, room temperature, and room noise levels. The quality of the patient's sleep at night needs to be considered and to increase comfort. Sleep quality starts from patient readiness, environment and comfort and the patient's condition are getting better. Poor sleep quality can affect a patient's stress condition. Patients who experience sleep disorders will improve the patient's pain response. An environment that is not good for sleep can improve the patient's pain response.

WHO in 2004 ventilator patients reached thirteen million to twenty million people each year. America from 2005 to 2007 critical patients reached five million and forty-two percent installed mechanical ventilators (Syifa, 2014). Southeast Asia from 16 ICU hospitals had 1285 ventilated sepsis patients up to 10 days 1. Pain patients from 722 patients had an average intensity of pain scale of 7.1. Patients who are critical after 24 hours have twenty percent experience pain (Sugiarto, 2015). The results of the literature review of nearly five million patients are treated at ICU and seventy-one percent of them complain of pain during treatment.

Pain in critical patients is likely due to environmental factors, namely lighting, temperature, and room noise. Patients have complaints of pain caused by a patient's illness. Pain complaints from the effects of therapy and procedures given to patients, nursing procedures that often cause pain include, changes in the position of the patient, suctioning of mucus from the trachea in patients with mechanical ventilation, wound dressing replacement and catheter installation, systematic and consistent pain assessment it is needed in critically ill patients who have ventilators, however, most patients who are attached to a ventilator cannot communicate pain verbally so that it is necessary to assess standardized pain. Pain is generally divided into two, namely neuropathic and nociceptive pain. Neuropathic pain is pain in the distal part of a nerve lesion or dysfunction, sensation is not always in accordance with stimulus, feeling hot, throbbing, painful, chronic, persistent after injury heals, does not have a protective function while nociceptive pain is localized to the place of injury, sensation according to stimulus, acute has a time limit, has a protective function, therefore, the benefits of pain assessment is one of them is to distinguish the type of pain, determine the scale of pain, and the concentration of localized pain or not.

Sleep disturbance factors during ICU care are physiological factors, routine nurse, environmental, and psychological actions. Physiological factors, which cause high levels of sleep disorders are a pain, shortness of breath, and coughing. The majority of clients perceive nurses 'actions at night are generally only mild sleep disturbances, including nurses' actions towards other clients, measuring vital signs, and giving medication.3 Environmental factors that interfere with client's sleep at light-moderate levels namely noise from various sources, temperature hot room, and the lights are too bright

\section{METHODS}




\section{STRADA Jurnal Ilmiah Kesehatan}

DOI: $10.30994 /$ sjik.v9i1.266

ISSN: 2252-3847 (print); 2614-350X (online)

Vol.9 No.1. May 2020. Page.26-34

The research design is descriptive-analytic with factor analysis. The study population was all patients in the ICU. A sample ware 170 patients in the ICU according to the inclusion criteria, namely critical patients who have received 24-hour care. Independent variables are room temperature, lighting level, and noise level. The dependent variable is the level of pain. The research instruments were CPOT, lux meter, and light meter. Data were collected using observation sheets and analyzed using regression. The research permit has been obtained from the research site. The study was conducted after receiving a letter ethical clearance with letter number 024/01 / V / EC / KEPK / STIKES RSBK / 2019 and had obtained a research permit from the research site.

\section{RESULTS}

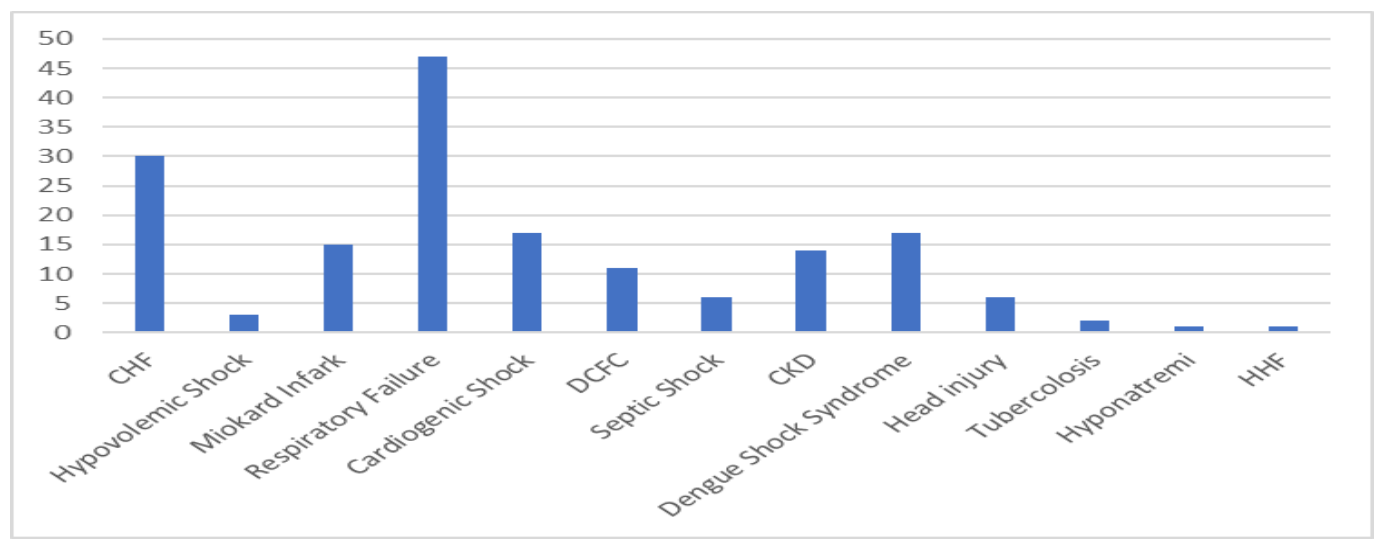

Figure 1 Characteristics of Patient Diagnosis

Based on Figure 1 shows the results of the study found that almost half of the respondents had a diagnosis of respiratory failure as many as 47 respondents (27.6\%),

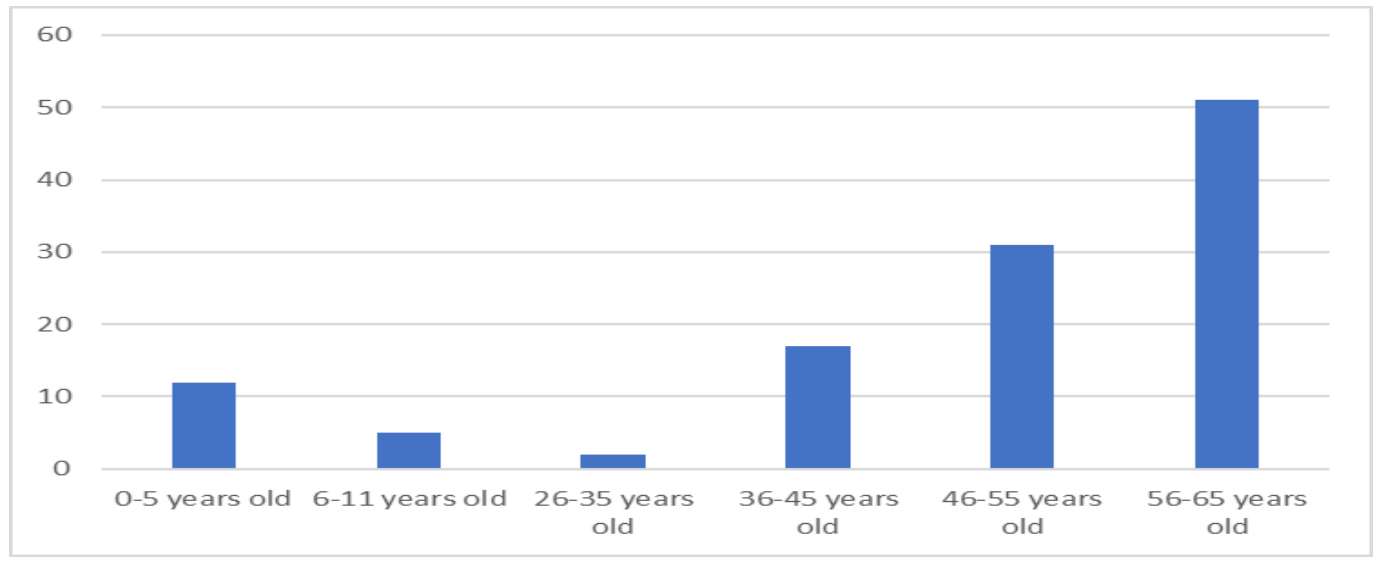

Figure 2. Characteristics of the patient's age 


\section{STRADA Jurnal Ilmiah Kesehatan}

DOI: $10.30994 /$ sjik.v9i1.266

ISSN: 2252-3847 (print); 2614-350X (online)

Vol.9 No.1. May 2020. Page.26-34

Based on Figure 2 shows the results of the study found that almost half of the respondents had an age of 56-65 years as many as 51 respondents (30\%).

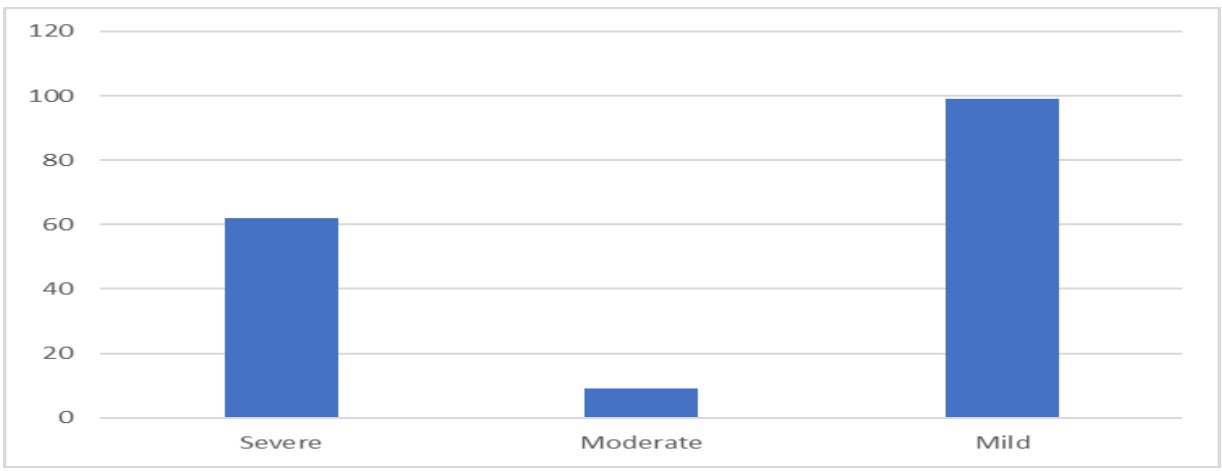

Figure 3. Characteristics Based on Glasgow Coma Scale patients

Based on figure 3, the results of the study show that almost half of the respondents received sedation as many as 61 respondents $(35.9 \%)$, with GCS the eye indicator had a mean and standard deviation of $2.91 \pm 1.38$. Verbal indicator GCS has a mean and standard deviation of $3.48 \pm 1.87$. The motive GCS indicator has a mean and standard deviation of $4.17 \pm 2.27$. The results of the study showed that most respondents had a low level of awareness.

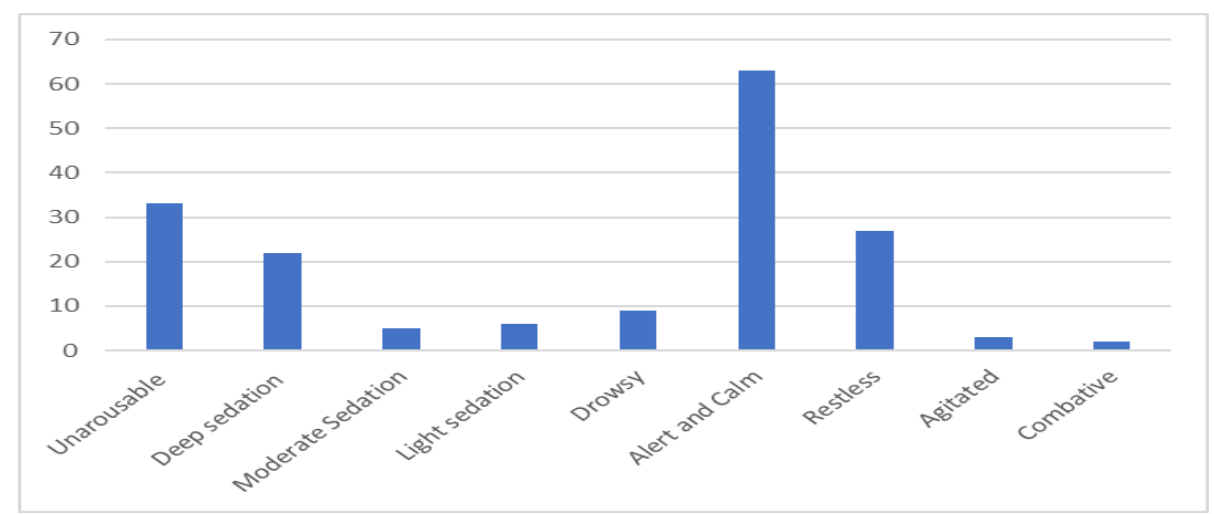

Figure 4. Characteristics of the Richmond Agitation Sedation Scale (RASS)

Based on Figure 4, the results of the study show that almost half of the respondents had the value of Richmond Agitation Sedation Scale (RASS), namely Alert and Calm as many as 63 respondents $(37.1 \%)$.

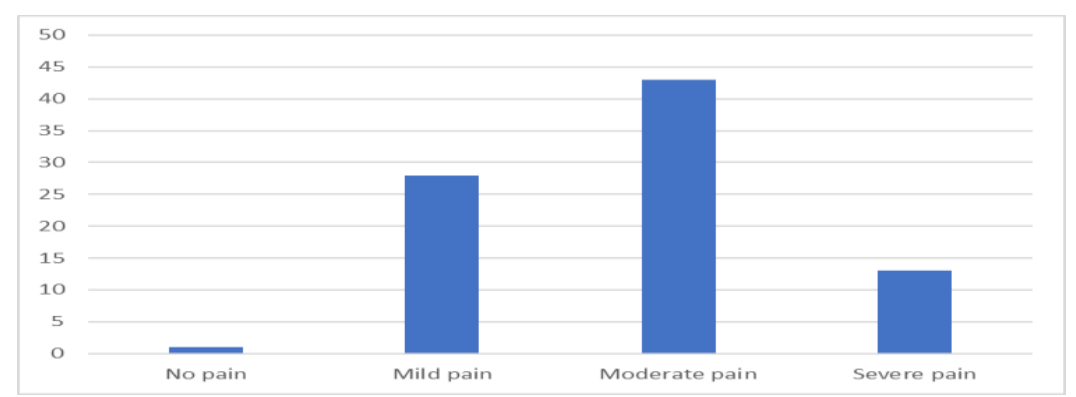

Figure 5. Characteristics of Critical Patient Pain Scale 


\section{STRADA Jurnal Ilmiah Kesehatan}

DOI: $10.30994 /$ sjik.v9i1.266

ISSN: 2252-3847 (print); 2614-350X (online)

Vol.9 No.1. May 2020. Page.26-34

Based on Figure 45, The results of the study on CPOT indicators on the Facial Expression study found that the same scores on tense and grimacing were 35 respondents $(41.2 \%)$, Body movements study found that almost half of the respondents showed 33 respondents of absent or normal position $(38,8 \%)$, assessment of Compliance with ventilator or Vocalization found that almost all respondents showed Tolerating ventilator or movement / Talking in normal tone / no sound by 66 respondents (77.6\%), tension Muscle study found that most respondents indicated Relaxed for 44 respondent $(51.8 \%)$. The results of the study showed that the pain scale based on CPOT most respondents had Moderate pain as many as 43 respondents $(50.6 \%)$.

Table 1. Characteristics of ICU Environmental Factors

\begin{tabular}{lccc}
\hline \multicolumn{1}{c}{ Environment Factors } & Mean & SD & P-value \\
\hline Lighting (lux) & 40,22 & 41,1 & 0,445 \\
\hline Noise (dba) & 60,53 & 8,5 & \\
\hline Temperature (Celcius) & 26,79 & 1,2 & \\
\hline
\end{tabular}

Based on Table 1, the results showed that the lighting environment (40.22 \pm 41.1$)$, noise $(60.23 \pm 8.5)$, and room temperature $(26.76 \pm 1.2)$ were not directly related to the patient's pain level.

\section{DISCUSSION}

The results of the study showed that there were effect environments factors of sleep hygiene care were not directly related to the patient's pain level. The factors are the lighting environment $(40.22 \pm 41.1)$, noise $(60.23 \pm 8.5)$, and room temperature $(26.76 \pm$ 1.2). The results of the study showed that there are most patients critical has 56-65 years of age and $>65$ years $(34.4 \%)$, most critical patients are female $(53.3 \%)$, almost half of critical patients have high school education (48.4\%), almost half of the critical patients as housewives $(32.8 \%)$, almost half of the critical patients had a diagnosis of respiratory failure (38.5\%), most critical patients received sedation (59\%) and most critical patients with disorders cardiovascular had severe cognitive impairment (38.5\%).

Critically ill patient with pain level was a representation resulting from feelings uncomfortable and experiences as long as the patient in the intensive care unit. Pain feelings of critical patients are very important to study because they can have an impact on the continuation of therapy and the severity of the condition of the next critical patient (Brown, Buboltz, \& Soper, 2010; Dakin \& Margarson, 2010; Hoffman \& Guttendorf, 2015). Environmental Factors can be affected by pain level from outside the ICU in critically ill patients with likely caused by age, sex, marital status, employment, education, smoking history, personal behavior, and previous mental health disorders. Pain level of critically ill patients acquired during ICU may be due to prognosis (Davidson, Harvey, Bemis-Dougherty, Smith, \& Hopkins, 2013; Parry et al., 2015; SandraG $\backslash$ G., Dominique, Dominique, Lieven, \& Johan, 2010), ICU care, airway status, use of mechanical ventilation, disease severity, length of treatment, and use of medication during treatment. Patients who survive in the ICU have symptoms of physical disorders, cognitive and psychological and such disorders can be complex. The negative impact of these disorders is a decrease in the quality of life of critical patients and the quality of sleep. Decreasing the quality of sleep can occur so that the patient leaves the ICU. Critically ill patients with pain and psychological impact and one of them in the form of anxiety are still related to 


\section{STRADA Jurnal Ilmiah Kesehatan}

DOI: $\underline{10.30994 / \text { sjik.v9i1.266 }}$

ISSN: 2252-3847 (print); 2614-350X (online)

Vol.9 No.1. May 2020. Page.26-34

the care of patients in the ICU individually (Bjorvatn, Fiske, \& Pallesen, 2011; Choi, 2016)

Result of research showed that environmental factors of sleep quality maybe we're not related to pain level. It is maybe there are others factor can relate to the pain level of critically ill patients. It is a very important aspect and needs to be considered in critically ill patients in the ICU. Human is not able to survive without sleep; the function of the human body is not able to function properly if it lacks sleep(Bjorvatn, Fiske, \& Pallesen, 2011; Park, 2014; Suwardianto, Prasetyo, \& Utami, 2017). Function Disorders that often occur if the patient has sleep poor quality, endocrine hormone disorders, immune disorders, metabolic disorders, and psychological process disorders. Body functions that accommodate sleep functions, namely CNS and memory consolidation. Sleep quality is very important for improving the condition of critically ill patients in the ICU. Factors that affect disturbances sleep in the ICU include actions besides the patient's bed, environment factors of sleep hygiene (temperature, noise, and light), delirium, inflammatory response, heart rhythm disturbances, stress, ventilator fighting, and treatment. Based on the results of the study, it was found that the majority of respondents had a poor experience with sleep quality, and mostly due to environmental factors are light, noise, stress, pain, and procedures for patient actions in the ICU. Ventilator installation procedures and ventilator settings can interfere with the patient's sleep quality (Matthews, 2011; Suwardianto, 2016; Suwardianto \& Kurnia, 2012). The impact is caused if the patient experiences impaired sleep quality in the form of anxiety and the patient's condition is getting worse.

Each hospital or ICU to meet the requirements of a lighting system must have natural lighting and/or artificial/mechanical lighting, including emergency lighting according to its function. Natural lighting must be optimal, according to the function of the hospital and the function of each room in the hospital. Artificial lighting must be planned based on the level of illumination required according to the function of space in the hospital by considering efficiency, saving energy used, and placing it not causing glare or reflection. The best patient room during sleep is a maximum of 50 lux.

Comfort to noise is a condition with a noise level that does not cause hearing, health, and comfort problems for someone in carrying out activities (Suwardianto \& Selvia, 2015). Noise disturbances in buildings can be at risk for hearing defects. To protect these disturbances, an acoustic environment is needed at the place of activity in existing buildings and new buildings (Evanthia, 2015; Jan et al., 2008; Wahyuningsih, 2016). To obtain a level of comfort against noise in a hospital building, it must consider the types of activities, use of equipment, and/or other noise sources both in buildings and outside of hospital buildings. Every hospital building and/or activity due to its function has a noise impact on the environment and/or on existing hospital buildings, must minimize the noise generated to the level permitted. For comfort against noise in hospital, buildings must be met with standard procedures for planning comfort against noise in buildings. Maximum noise when the patient sleeps is $40 \mathrm{dBA}$.

The temperature controller includes the operation of both heating and cooling systems to maintain temperature setpoints in different areas of the building. Cold temperatures $\left(20^{\circ} \mathrm{F}\right.$ $-22,7^{\circ} \mathrm{C}$ ) are usually associated with operating rooms, cleanroom rooms, and endoscopic suites. A warmer temperature $\left(23,8^{\circ} \mathrm{C}\right)$ is needed in areas that require greater degrees of patient comfort. Most other zones use a temperature range of $21^{\circ} \mathrm{C}-23,8^{\circ} \mathrm{C}$. Temperatures outside this range may be needed on limited occasions in limited areas depending on individual circumstances during patient care. 


\section{STRADA Jurnal Ilmiah Kesehatan}

DOI: $10.30994 /$ sjik.v9i1.266

ISSN: 2252-3847 (print); 2614-350X (online)

Vol.9 No.1. May 2020. Page.26-34

Critically ill patients in the ICU have a short sleep and sustained. Some critically ill patients have reversed sleep patterns so that critically ill patients have very little REM sleep phase. Critically ill patients understand that sleep disturbances are caused by heart rhythm disorders that they suffer, stress, and nursing actions performed (Faraklas, 2013; Stepanski \& Wyatt, 2003). Giving opioids and sedation can be a source of sleep quality disorders. Giving deep sedation can interfere with recovery and sleep quality and maybe it is not good for sleep patients. Sleep disorders can increase anxiety, then the management of sleeping patients in the ICU needs to be continuously developed so that the quality of sleep can be achieved and reduce anxiety. Environmental factors of sleep hygiene in improving sleep quality and reducing anxiety are very necessary. Nurses of ICU need to evaluate the noise level in the room by checking through a sound level meter (Barr et al., 2013; Skrobik, 2013). Critically ill patients can give the same nonpharmacologic therapy to support the quality of sleep patients in the night, or nurses can give education about room orientation or deep breathing according regularly. Critically ill patients with good comfort at moment patient sleep can increase endorphin hormone and decrease sympathies respond, and the finally hemodynamic will recovery. Critical patients with mechanical ventilators will better use assist-control mode at night to improve sleep in critically ill patients, and the need for multicomponent, non-pharmacologic intervention to reduce the possibility of delirium, improve cognitive function and optimize sleep, mobility, hearing, vision in critical patients in the ICU. Environmental of Sleep hygiene is a supporter of critical patient sleep in the ICU. The use of earplugs and eye masks in some patients is indeed needed to support sleep quality and reduce anxiety levels. Mobilization exercises before going to bed, giving music therapy, back massage or foot massage and distraction are also needed for several conditions.

\section{CONCUSSION}

Based on result showed that there are most patients with critically ill has 56-65 years of age and > 65 years, most critically ill patients are female, almost half of critically ill patients have high school education, almost half of the critically ill patients as housewives, almost half of the critically ill patients had a diagnosis of respiratory failure, most critically ill patients received sedation and most critical patients with disorders cardiovascular had severe cognitive impairment. The results showed that the lighting environment, noise, and room temperature were not directly related to the patient's pain level.

\section{ACKNOWLEDGMENTS}

We are researcher says thank full to the Ministry of Science, Research, Technology and Higher Education of Indonesia (RISTEKDIKTI RI) for Research Grants 2018 and providing 2019. We thank you to Director of Kediri Baptist Hospital, Nurse in the ICU Baptist Hospital ICU and all research respondents.

\section{REFERENCES}

Barr, J., Fraser, G. L., Puntillo, K., Ely, E. W., Devlin, J. W., Kress, J. P., ... Jaeschke, R. (2013). Clinical practice guidelines for the management of pain, agitation, and delirium in adult patients in the intensive care unit. Society of Critical Care Medicine, The American College of Critical Care Medicine (ACCM), 41(1), 263306. 


\section{STRADA Jurnal Ilmiah Kesehatan}

DOI: $10.30994 /$ sjik.v9i1.266

ISSN: 2252-3847 (print); 2614-350X (online)

Vol.9 No.1. May 2020. Page.26-34

Bjorvatn, B., Fiske, E., \& Pallesen, S. (2011). A self-help book is better than sleep hygiene advice for insomnia: A randomized controlled comparative study. Scandinavian Journal of Psychology. https://doi.org/10.1111/j.1467-9450.2011.00902.x

Brown, F. C., Buboltz, W. C., \& Soper, B. (2010). Development and evaluation of the sleep treatment and education program for students (STEPS). Journal of American College Health : J of ACH. https://doi.org/10.3200/JACH.54.4.231-237

Dakin, J., \& Margarson, M. (2010). Current Anaesthesia \& Critical Care Sleep-disordered breathing and anaesthesia in the morbidly obese. Current Anaesthesia \& Critical Care, 21(1), 24-30. https://doi.org/10.1016/j.cacc.2009.10.008

Davidson, J. E., Harvey, M. a, Bemis-Dougherty, A., Smith, J. M., \& Hopkins, R. O. (2013). Implementation of the pain, agitation, and delirium clinical practice guidelines and promoting patient mobility to prevent post-intensive care syndrome. Critical Care Medicine, 41(9 Suppl 1), S136-45. https://doi.org/10.1097/CCM.0b013e3182a24105

Evanthia, G. (2015). The Impact of Pain Assessment on Critically Ill Patients' Outcomes: A Systematic Review. Biomed Res Int, 1(1).

Faraklas, I. (2013). Impact of a Nursing-Driven Sleep Hygiene Protocol on Sleep Quality. Journal of Burn Care \& Research, 34(2), 249-254.

Hoffman, L. A., \& Guttendorf, J. (2015). Post Intensive care syndrome: risk factors and prevention strategies. Retrieved January 1, 2016, from AHC media website: https://www.ahcmedia.com/articles/134820-post-intensive-care-syndrome-riskfactors-and-prevention-strategies

Jan, J. E., Owens, J. A., Weiss, M. D., Johnson, K. P., Wasdell, M. B., Freeman, R. D., \& Ipsiroglu, O. S. (2008). Sleep Hygiene for Children With Neurodevelopmental Disabilities. Pediatrics. https://doi.org/10.1542/peds.2007-3308

Matthews, E. E. (2011). Sleep Disturbances and Fatigue in Critically Ill Patients. AACN Advanced Critical Care, 22(3), 204-224. https://doi.org/10.1097/NCI.0b013e31822052cb

Park, J. M. (2014). Assessment and Treatment of Pain in Adult Intensive Care Unit Patients. Korean J Crit Care Med, 29(3), 147-159.

Parry, S. M., Denehy, L., Beach, L. J., Berney, Su., Williamson, H. C., \& Granger, C. L. (2015). Functional outcomes in ICU - what should we be using? - an observational study. Critical Care, 19(127), 1-9. https://doi.org/10.1186/s13054015-0829-5

SandraG $\backslash$ G., O., Dominique, V., Dominique, B., Lieven, A., \& Johan, D. (2010). Quality of life after intensive care. Critical Care Medicine, 38(12), 2286-2400.

Skrobik, Y. (2013). The pain, agitation, and delirium practice guidelines for adult critically ill patients: a post-publication perspective. Ann Intensive Care, 3(9).

Stepanski, E. J., \& Wyatt, J. K. (2003). Use of sleep hygiene in the treatment of insomia. Sleep Medicine, 7(3), 215-225.

Sugiarto, A. (2015). Intervensi Berbasis Keperawatan Integrasi dengan Relaksasi Islami terhadap Penurunan Kecemasan dan Nyeri Pasien AMI di Ruang ICU. LINK, 11(3), 1017-1025.

Suwardianto, H. (2016). Tardive dyskenesia, motor activity, sedation scale, dan cardiac workload pasien IPI pada pemberian analgesik di instalasi perawatan intensif RS. baptis kediri. Keperawatan Kritis, Penelitian Hibah YBI.

Suwardianto, H., \& Kurnia, E. (2012). Pengaruh Terapi Relaksasi Napas Dalam (Deep Breathing) Terhadap Perubahan Tekanan Darah Pada Penderita Hipertensi di 


\section{STRADA Jurnal Ilmiah Kesehatan}

DOI: $10.30994 /$ sjik.v9i1.266

ISSN: 2252-3847 (print); 2614-350X (online)

Vol.9 No.1. May 2020. Page.26-34

Puskesmas Kota Wilayah Selatan KOta Kediri (Vol. 4).

Suwardianto, H., Prasetyo, A., \& Utami, R. Su. (2017). Physical Function-Tardive Dyskenesia (PATD) on Critical Patients in Intensive Care Unit. Jurnal Ners, 12(2). https://doi.org/http://dx.doi.org/10.20473/jn.v12i2.4504

Suwardianto, H., \& Selvia, D. (2015). Buku Ajar Keperawatan Kegawatdaruratan (Perspektif, Konsep, Prinsip, dan Penatalaksanaan Kegawatdaruratan). Surabaya: PT. REVKA PETRA MEDIA.

Syifa. (2014). Pengaruh mobilisasi progresif level i: terhadap risiko dekubitus dan perubahan saturasi oksigen pada pasien kritis terpasang ventilator di ruang icu rsud dr. Moewardi surakarta. Universitas Deponegoro, 1(1), 1.

Wahyuningsih, I. sri. (2016). Uji sensitivitas dan spesifitas confort scale untuk meniilai nyeri pasien kritis dewasa dengan ventilator di intensive care unit. Universitas Diponegoro. 